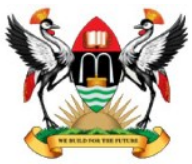

East African School of Higher Education Studies \& Development

\title{
Aliu Babatunde Fafunwa's Philosophy of Education
}

\author{
A. F. Oyelade ${ }^{1}$ \\ ${ }^{1}$ Department of Arts Education, Faculty of Education, University of Ilorin [*E-mail: \\ afoyelade@gmail.com]
}

\begin{abstract}
As the first indigenous Nigerian professor of Education and as a highly influential Nigerian Minister of Education, Aliu Babatunde Fafunwa is distinguished and honoured in Nigeria and elsewhere as a thought leader in the area of education. It is with this understanding that this study traced his philosophy of education with the view to highlight the underpinnings, meanings and significance of his views and actions. Using logical, linguistic, critical, and expository analyses, the study concluded that his worldview and work typify a philosophy of cultural reconstruction. The philosophy stresses continuous cultural reconstruction of society through education - for sustainable development of the society. It is argued that the philosophy has implications for education and development in Nigeria. Therefore, it is recommended for the country and similar countries.
\end{abstract}

Keywords: Aliu Babatunde Fafunwa; Philosophy; Reform.

\section{$1 \quad$ Introduction}

This paper examines Aliu Babatunde Fafunwa's thoughts on education. These thoughts are found in his speeches, publications and actions at various times, at various stages of his life/ career. He was born in 1923 in Lagos, Nigeria and was the first Nigerian to be appointed professor of Education (Aladejana \& Alao, 1992:15). Moreover he had many landmark achievements during his work experience in various areas of life.

His speeches, publications and actions indicate his thoughts about education and life generally. These are what would be analysed in this paper as his philosophy of education. This is important because Fafunwa although a Nigerian has demonstrated a lot of thoughtfulness about education. His thoughts have not been given serious attention, as it should be, like the thoughts 
of some other renowned thinkers. Only a few people have focused on his thoughts in education (see for instance Aladejana \& Alao, 1992).

As would be found out in the course of the analysis of his thoughts it would be realised that he has very profound thoughts about education. This qualifies him for attention in terms of analysis of his philosophy of education. This paper would therefore examine his thoughts in his early years (up to the end of his Ph.D. degree studies); his thoughts during his early work days; his thoughts as university lecturer; as minister of education in Nigeria; and subsequently, in order to analyse into some details, his philosophy of education.

The method adopted featured logical, linguistic, critical, and expository analysis of his thoughts as found in his speeches, publications and actions. It is hoped that the analysis will help to clarify Fafunwa's ideas on education and the implications of these ideas for education generally, and for education in Nigeria in particular.

\section{Fafunwa's Work and Philosophy of Education}

\subsection{Early Years and Thoughts about Education and Life}

Aliu Babatunde Fafunwa (popularly known as Babs Fafunwa) was born in 1923 in Lagos, Nigeria. His parents engaged in farming and petty trading for livelihood. He was part of their life and livelihood experience as he had to farm and trade with them (Fafunwa, 1991:6; see also Aladejana \& Alao, 1992:20). Thus he had hectic elementary school days. His parents were not rich. However he was lucky to attend secondary school in 1937; it was on the invitation of an uncle, Pa William Kudehinbu Fafunwa (Aladejana \& Alao, 1992:3, 4). In those days in Nigeria attendance of primary and secondary schools was not automatic. Thus only very few children attended elementary and secondary schools. At the secondary school (C.M.S. Grammar School) he performed well in his studies and behaved well to the extent that he was made the class captain in his final year (Aladejana \& Alao, 1992:4). To achieve secondary education at that time was like achieving final education because there was no university in Nigeria then. The first university (the university college Ibadan was established in 1948). He worked for three years after his secondary school $(1944-1947)$ in the Nigerian Railways at Lagos as a clerk and he saved virtually all the salary he earned, to be able to travel to the United States of America to pursue a university degree. In 1947 he gained admission into Bethune-Cookman College, Daytona, Florida, in the United States of America and travelled to commence his studies. He finished his Bachelor's degree studies in Education in 1951 and proceeded through the support of a philanthropist (Mrs Louise Lawrence Meigs) to pursue his Master's degree in New York University in 
1951. He immediately proceeded to do his Doctorate degree studies after completing his Master's degree in the same university through doing some part time work, before he was finally appointed as Assistant Nigerian Liaison Officer for the Nigerian and Sierra Leonean students at the British Embassy and Nigerian office based in Washington D.C. He completed his $\mathrm{PhD}$ degree studies in Education in 1955.

It follows that Fafunwa had hectic time pursing his studies right from primary school up till his final studies in the university. This is to indicate that Fafunwa never had his education under easy circumstances. He struggled throughout. He always had it in his mind that education is a way to achievement in life, so he was always undaunted going through the constant obstacles that featured virtually throughout his days as pupil and student at the elementary, secondary and tertiary educational institutions.

His objective was to secure education and thereby be free from want and become an achiever. His thought is that education could make one free oneself from the servitude level of colonial dependency to the level of independent citizen of a sovereign nation (Fafunwa, 1991a: 46, 48). So he thought education must be pursued as an instrument of freedom (Fafunwa, 1991a: 46, 48), social progress (cultural progress) (Fafunwa, 1991a: 46, 48), and economic progress (Fafunwa, 1991a: 46, 48).

It would not only be a viable instrument of freedom from the shackles of colonialism but also a viable instrument of progress after colonialism would have been conquered and independence attained. Thus at independence it would help in political progress, social and cultural progress and economic progress. It is the thoughts of Fafunwa in these regards, and the demonstration of the genuineness of his thoughts in his life endeavours that constitute his philosophy of life and particularly his philosophy of education.

\subsection{Early Experience and Thoughts about Civil Responsibility}

After graduating in 1955 with a Ph.D. degree in education, Aliu Babatunde Fafunwa came back to Nigeria with his wife and child. He first worked in a secondary school, Ahmadiyya College, Agege, Lagos, for one year (January December, 1956) as a senior tutor and vice principal. During the period he initiated the teaching of civics in the curriculum of the school, to assert the need to teach civil responsibilities in the schools, which at that time was not part of the subjects taught in the secondary schools (Aladejana \& Alao, 1992:10, 11).

\subsection{ESSO West Africa and Thoughts on Practical Education}

Fafunwa worked in An Oil Company and Demonstrated that Education should De-emphasise Certification and Emphasise Practical Achievement of School 
Leavers. In 1957 Fafunwa worked in ESSO West Africa Limited (an international oil company) in Lagos, where he was appointed as EmployeePublic Relations Manager. During his tenure at the company (1957 - 1961), he initiated the employment of Nigerians at management level to convince himself and demonstrate to the colonial masters that Nigerians could hold managerial positions creditably if given the opportunity. The Nigerians he helped to get employment in the foreign company performed creditably to the satisfaction of the foreigners.

He also employed some people who failed school certificate examination in the foreign company, although these people demonstrated good disposition to hard work and learning. The people also performed creditably to the satisfaction of the foreign company (Aladejana \& Alao, 1992:11, 12). Fafunwa was pleased that he used this position to demonstrate that failure in examination is not failure in life (Aladejana \& Alao, 1992:11, 12). At that time schooling in Nigeria was examination oriented to the extent that the process of schooling largely involved passing examination, such that education could not be thought of without passing examination.

Fafunwa thus started initiating the thought that schooling and indeed education could be thought of without examination, in the sense that practical achievement matters more than examination certification. Indeed there are a lot of people who have lofty qualifications in various areas of educational specialisation, yet who in their various employments in the society have not positively impacted on the socio-economic milieu for the progress of the society. Whereas there are some with little education who have brought about positive change in the Nigerian society. Fafunwa had had that thought before Nigeria's independence and had pursued the demonstration of the thought when he had the opportunity to do so at ESSO Oil Company.

It follows that the thoughts of Fafunwa about education that places more emphasis on achievement than on examination is good. He thought about it, he demonstrated it when he had the opportunity in the pre-independence Nigeria and he was confirmed to be right.

\subsection{University of Nigeria and Ideas about Education in Nigeria}

In post-independence Nigeria after working in ESSO for some years (1957 1961) he sought appointment at the University of Nigeria, Nsukka, and got it in June 1961. The university was founded in 1960 almost immediately after independence, he was appointed (as a Senior Lecturer) in the Department of Education along with some other Nigerians and two foreigners (John Hanson and J. P. D. de Turville). John Hanson who was the head of Department left the university in 1962, and Fafunwa subsequently became the head of Department. He became a Professor in 1965 (Aladejana \& Alao, 1992:15). He was thus the 
first Nigerian to be appointed Professor of education (Aladejana \& Alao, 1992:15). In the same year (1965) he was appointed Dean of Education.

As Dean of Education he initiated a lot of ideas in the process of education (along with his team of lecturers in the Faculty of Education). Some of them are: The Faculty was the first to start Bachelor of Education degree programmes wherein the subject matter (teaching subjects) is taught along with pedagogical content (courses like educational psychology, philosophy, methodology and so forth). Before this time professional teachers who finished from the first university established in Nigeria (University College Ibadan, established in 1948) would pursue either B. A. or B.Sc. degrees programmes and then pursue Postgraduate Diploma in Education (usually a nine-month course of studies) in addition to the Bachelor's degree.

In subsequent years (1962 and afterwards) many other Nigerian universities started following the practice of the Faculty of Education, University of Nigeria, Nsukka under the leadership of Professor Aliu Babatunde Fafunwa. Moreover it was during his leadership in the Faculty of Education that the Faculty initiated the Nigeria Certificate in Education Courses (NCE) (Aladejana \& Alao, 1992:15, 16). The programme of studies was initiated to serve as the minimum professional qualification for teachers in Nigeria (Aladejana \& Alao, 1992:15, 16). But after a few years the NCE courses which started as a university of Nigeria, Nsukka, initiative became College of Education studies pursued outside university arrangement in various Colleges of Education.

It would be interesting to think that what Nigeria now has today as Colleges of Education were initiated first in Nigeria as Nigeria Certificate in Education Courses in the Faculty of Education, University of Nigeria Nsukka, under the leadership of Fafunwa. Moreover the long vacation courses for Grade II teachers for their professional development were initiated first by Fafunwa in the Faculty of Education, University of Nigeria, Nsukka (UNN) (Aladejana \& Alao, 1992:16).

\subsection{University of Ife and Ideas for Reform}

In 1967 Aliu Babatunde Fafunwa moved to the University of Ife (now Obafemi Awolowo University, Ife) as a result of the civil war in Nigeria. He also started the Faculty of Education there and was the first Dean of Education. $\mathrm{He}$ replicated all his new ideas in Nsukka at Ife and added the emphasis of mothertongue education for primary school children. He had the Mother-Tongue Primary Education Project whereby he demonstrated that when a child learns largely through his native language he would learn better and achieve more than when he learns largely through a foreign language (Aladejana \& Alao, 1992:78-93; Hallmarks of Labour, 2017). 


\subsection{Minister of Education (1989-1993)}

Fafunwa was appointed Minister of Education in 1989 in Nigeria and he also initiated a lot of new ideas in the Nigerian system of education. These were at the Primary, Secondary and University levels.

\subsubsection{Primary Level}

He thought that education should be free and a right of every citizen for enlightenment and progress in intelligence and functionality; although he could not pursue its implementation because of certain constraints of the military government under which he served as minister (Fafunwa, 1991b). In an address he delivered to the $6^{\text {th }}$ Annual Congress of the Nigerian Academy of Education in 1991 he stated that he wanted Education for all by the year 2000 to the extent that he proposed the idea of "each one teach one relative or fund the education of one relative" (see also Aladejana \& Alao 1992: 176).

In addition, Fafunwa would want the details of the features of Education for All as deliberated upon in the International Council on Education on Teaching, in Lagos, Nigeria on 22-26 July 1991 to influence Nigerian education. Among the details are;

1. Universalizing access and promoting equity

2. Recognition of individual differences in learners

3. Relevance should be reflected in the school curricular, materials and methods (Aladejana \& Alao, 1992:178, 179).

Finally Fafunwa thought that primary education should feature the following contents even before he became minister of education:

1. Reading and Writing in Child's Mother-tongue, English and French.

2. Arithmetical and Mathematical Processes.

3. Basic Science.

4. Civics and Social Studies.

5. Vocational Education.

6. Physical Education (Fafunwa, 1967; Aladejana \& Alao, 1992).

\subsubsection{Secondary Level}

He thought that education should pursue development of intelligence, arts disposition, science disposition, vocational disposition and cultural development. Moreover he thought that education should pursue moral development (Fafunwa, 1991a; see also Fafunwa, 1967:25, 26).

\subsubsection{University Level}

He thought that education should pursue research for the exploration of the natural and social environment towards the natural and social development of 
the society (Fafunwa 1991a; see also Fafunwa 1961:4-5). He also thought that at this level, education should pursue the development of the culture of the society by exploring the culture of the society towards the promotion of what is good in the culture and rejection of what is bad in the culture (Fafunwa 1991a; see also Fafunwa 1961:4-5).

He states that the developed nations that are at the vanguard of development today learn through their various cultures (Fafunwa 1991a; see also Fafunwa 1967:25-26, 146). Thus he insists that Nigeria should not abandon its culture in the bid to make educational and societal progress, rather it should look through its culture, pick the good aspects of the culture and reject the bad aspects. By the same token Nigeria should use the good aspects of other people's culture and reject the bad aspects of other people's cultures (Fafunwa 1991a; see also Fafunwa 1961:4-5).

The culture of nonchalant disposition to bad happenings in the society encourages the continuation of bad happenings and the deterioration of the socio-political milieu. This is what Paulo Freire regards as the culture of silence (Freire, 1972:97-150). Such culture helps no nation. Unfortunately such culture features at various times in Nigeria with its attendant discouragement of development in the socio-political milieu (Aladejana \& Alao, 1992:122; see also Fafunwa, 1961:4-5). Fafunwa thought that such culture should not be allowed and it was in this regard that he (in his capacity as minister of education) allowed the Academic Staff Union of Nigerian Universities (ASUU) to regroup, conduct itself democratically, and pursue its academic mandate of teaching, research and community service, in ways that would impact on the progress of the Nigerian society (Aladejana \& Alao, 1992:122; see also Fafunwa, 1967:146).

\subsubsection{Mass Education}

Fafunwa considers education to be so important in the reconstructionism of the culture of the society to the extent that, as minister of education, he suggested that each educated person should teach an uneducated person or fund the education of an uneducated person. He felt that by so doing the whole society would be educated within a short space of time (Fafunwa, 1991b). This idea was accepted in later years by the Nigerian government as part of its strategies for achieving mass education (see FRN, 1998:36; 2004:26; 2013:43) although it is not pursued realistically.

It is in connection with the foregoing thoughts and actions of Fafunwa in various spheres of life that Fafunwa's philosophy of education can be regarded as philosophy of cultural reconstructionism. The philosophy considers education to be central to human development, and considers the teacher to be at the centre of that process. In addition it considers culture of the people as an 
important ingredient of man's life which needs to be continuously reconstructed for the development of man and the society. The education sector of the society needs to act on the society in a centripetal manner so that the society can develop along the line of genuine education and culture (Counts 1932; Counts 1934:70-73; Fafunwa, 1991b; Fafunwa 1961:4, 5).

\subsubsection{Thoughts after Tenure as Minister of Education}

After his tenure as minister of education, Fafunwa still thought of education in terms of education for cultural reconstructionism, as can be seen from his speeches, publications and actions in his subsequent areas of responsibilities (Hallmarks of Labour, 2017).

\section{Conclusion}

Aliu Babatunde Fafunwa's philosophy of education has been analysed and it is seen to feature philosophy of cultural reconstructionism. This is a modern philosophy of education that places emphasis on constant reconstruction of man's culture for the development of man and his society. It places emphasis on education and particularly on the teacher as the initiator of that cultural reconstruction. It appears to be of great importance to explore our culture regularly for the purpose of reconstruction and subsequent development of man and the society. However other people's cultures also need to be explored by our education for reconstruction and utilisation in our society for the development of the society (Counts, 1932:17-18; Counts, 1934:70-73).

Fafunwa has been found to think in the line of cultural reconstructionism since his early work days at the Nigerian Railways, up till his work days as a Ph.D. degree holder in Ahmadiyya College; Esso; and in the University of Nigeria, Nsukka; and University of Ife (now Obafemi Awolowo University, Ife). Further he retained his thought of cultural reconstructionism as minister of education and even afterwards. His thoughts and actions in the various fields of endeavours show his conviction about the philosophy of cultural reconstructionism as a viable philosophy of life and of education.

\section{$4 \quad$ Recommendations}

The philosophy of cultural reconstructionism lays emphasis on exploration of culture for cultural reconstruction. It also asserts that education is the instrument that can help to achieve the desired exploration and cultural reconstruction and consequently the development of the society. It can be found 
that the more education a people has the more developed the people appear to be. For instance the developed nations (like United States of America, United Kingdom, France, Germany, Japan, and Russia) insist on granting free education to their citizens up to the end of secondary school education. The education includes general education, functional and vocational education. This makes the citizens to be more enlightened and the societies to engage in more constant reconstruction of their cultures.

On the contrary, the developing nations like Nigeria, and many other African nations grant free education that does not go as far as the end of secondary school education. By so doing the developing nations like Nigeria are not helping so much in the exploration of culture for cultural reconstruction and consequently in the development of the society.

It is therefore recommended that as Fafunwa suggests (Fafunwa, 1991b) the Nigerian society should grant free education to a greater number of people. In this regard the end of senior secondary school education (as it is in the developed nations mentioned above) should be the end of free education; not the end of junior secondary school education. Moreover at that level, the education should feature general education, functional education, and vocational education.

Finally at the tertiary level of education, the students and teachers should be granted a lot of freedom to conduct research in all areas of education for the exploration of the culture of the society towards the reconstruction of the culture and the society for the development of man and the society. This is to suggest that freedom should be granted to conduct research into other people's cultures too; so that whatever is good in the various cultures could be used for the development of the society.

\section{References}

Aladejana, T. I. \& Alao, K. (1992). Aliu Babatunde Fafunwa: His educational philosophy and contributions to Nigerian education. Ibadan: Adefila Commercial Printers.

Counts, G. S. (1932). Dare the schools build a new social order? New York: The John Day Company Inc.

Counts, G. S. (1934). The social foundations of education. New York: Charles Scribner \& Sons.

Fafunwa, A. B. (1961). "Wanted: a new approach to education in a new Nigeria". Lagos: Daily Times, Pp. 4-5.

Fafunwa, A. B. (1967). New perspectives in African education. Ibadan: Macmillan and Co. Nigeria Limited. 
Fafunwa, A. B. (1991a). The changing pattern of education in Nigeria. A Public Lecture Delivered by the Honourable Minister of Education, Professor Aliu Babatunde Fafunwa on $21^{\text {st }}$ May, 1991.

Fafunwa, A. B. (1991b). An address delivered by the Honourable Minister of Education, Professor Aliu Babatunde Fafunwa, at the $6^{\text {th }}$ Annual Congress of the Nigeria Academy of Education held in Ahmadu Bello University, Zaria on $23^{\text {rd }}$ September, 1991.

Fafunwa, A. B. (1991). Up and On! A Nigeria teacher's odyssey. Lagos: West African Book Publishers Ltd.

Federal Republic of Nigeria (FRN). (1998). National policy on education (revised), Lagos: NERC Press

Federal Republic of Nigeria (FRN). (2004). National policy on education (revised), Lagos: NERC Press

Federal Republic of Nigeria (FRN). (2013). National policy on education. Lagos: NERDC Press

Freire, P. (1972). Pedagogy of the oppressed. Harmondsworth: Penguin Books.

Hallmarks of Labour: http//:www.hallmarksoflabour.org/citations/prof-aliubabatunde-fafunwa-nnom-cor.hlr/ Retrieved $15^{\text {th }}$ February, 2017. 